\title{
PENGARUH METODE TOTAL PHYSICAL RESPONSE TERHADAP PENGUASAAN MUFRODAT SISWA SEKOLAH DASAR
}

\author{
Ary Kurniawati, Nurhapsari Pradnya Paramita, \\ Dailatus Syamsiyah \\ UIN Sunan Kalijaga Yogyakarta \\ Pradnyaparamita2219@gmail.com
}

\section{ملخص}

المفردات عنصر مهم في تعليم اللغة العربية. الممارسات التعليمية التي وجدها المؤلفون في تعليم اللغة العربية، وخاصة المفرودات، لا تزال تستخدم طريقة

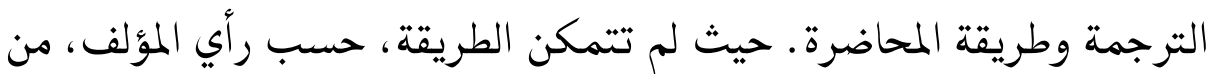
زيادة إتقان الطلاب للمفردات بشكل ملحوظ. يهتم الباحث باستخدام طريقة الاستجابة الفيزيائية الكلية (TPR) كسكين في تحسين قدرة المفردات لدى الطلاب. كان الغرض من هذه الدراسة هو تحديد آثار تعليم المفردة باستخدام طريقة الاستجابة الفيزيائية الكلية. وتأثير طريقة الاستجابة الفيزيائية الكلية على إتقان المفردة في واحدة من المدرسية قي هذا البحث عبارة عن تصميم مقارنة مجموعة سليمة لأبحاث ما قبل التجربة. استخدمت تقنية أسندة أخذ العينات أخذ العينات الكلي . قام الباحث بتقسيم الفصل إلى قسمين لهما نفس القدرة التوزيعية للطلاب وهما المجموعة التجريبية باستخدام طريقة الاستجابة الفيزيائية الكلية والمجموعة الضابطة باستخدام طريقة الترجمة . أظهرت النتائج وجود اختلاف في فهم المفرود بين الصنفين التجريبي والضابط. أظهرت نتائج معالجة البيانات وجود فروق ذات دلالة إحصائية، لذلك استنتج أن هناك تأثيراً 
Ary Kurniawati, Nurhapsari Pradnya Paramita, Dailatus Syamsiyah : Pengaruh Metode Total Physical Response Terhadap Penguasaan Mufrodat

Siswa Sekolah Dasar

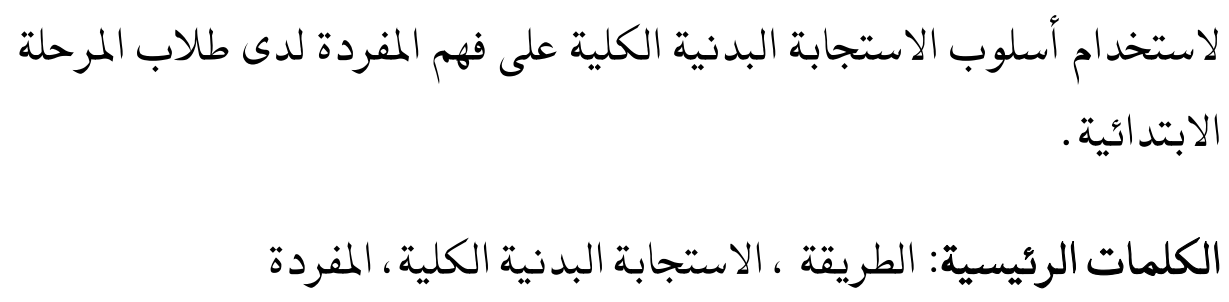

\section{Pendahuluan}

Problematika utama dalam pembelajran bahasa arab cenderung dikarenakan siswa kurang menguasai kosakata (mufrodat). Penyebab kurangnya penguasaan mufrodat siswa salahsatunya disebabkan karena metode yang digunakan guru cenderung monoton. Dilapangan ditemukan mayoritas guru mengajarkan mufrodat maupun bahasa arab secara umum menggunakan metode terjemah dan ceramah. Jarang sekali guru yang memiliki inovasi/ kreativitas dalam penggunaan metode maupun media pembelajaran. Oleh karena itu inovasi metode pembelajaran mufrodat menjadi sesuatu yang diperlukan.

Metode total physical response atau sering disebut metode total fisik respon merupkan salah satu metode pembelajaran yang menarik. Metode ini mengoptimalkan seluruh bekal siswa dalam belajar. Menurut Ghazali (2010) Total Physical Response (TPR) merupakan metode pembelajaran bahasa yang menggunakan perintah-perintah lisan dengan tujuan agar siswa dapat menunjukkan pemahamannya terhadap maksud dari perintahperintah lisan itu. Melalui penerapan metode TPR dalam pengajaran kosakata bahasa Arab, siswa secara langsung dapat 
Ary Kurniawati, Nurhapsari Pradnya Paramita, Dailatus Syamsiyah : Pengaruh Metode Total Physical Response Terhadap Penguasaan Mufrodat Siswa Sekolah Dasar

mengetahui makna kosakata tersebut tanpa harus meraba-raba makna kosakata itu sendiri. Karena dengan peragaan secara otomatis siswa secara langsung dapat mengetahui makna kosakata tanpa melaui metode terjemah.

Sebagaimana teori multiple intelegences bahwa masingmasing individu memiliki kecerdasan yang berbeda. Gardner membagi kecerdasan menjadi 9, diantaranya kecerdasan verballinguistik, kecerdasanlogis-matematis, kecerdasan visual-spasial, musikl, kinestetis, interpersonal, intrpersonal, naturalis dan eksistensial. Dalam pembelajaran bahasa arab menggunakan metode TPR ini, dapat mengcounter beberapa kecerdasan yang dimiliki siswa. Sehingga diharapkan hasil pembelajaran mufrodat menjadi lebih optimal. Artikel ini bertujuan untuk mengetahui : 1) apakah terdapat perbedaan antara pemahaman kosakata antara kelas experiment dan kelas kontrol, 2) apakah terdapat pengaruh metode total physical response dalam penguasaan mufrodat pada pelajaran bahasa arab siswa SD Qurrota A'yun Yogyakarta?

\section{Pemahaman Metode Total Physical Response}

Menurut Richards J dalam bukunya Aprroaches and Methods in Language Teaching, TPR didefinisikan suatu metode pembelajaran bahasa yang dibangun atas koordinasi perintah (command), ucapan (speech), dan gerak (action), serta berusaha untuk mengajarkan bahasa melalui aktivitas fisik. Metode ini dikembangkan seorang psikologi di Universitas San Jose California yang bernama James J. 
Ary Kurniawati, Nurhapsari Pradnya Paramita, Dailatus Syamsiyah : Pengaruh Metode Total Physical Response Terhadap Penguasaan Mufrodat

Siswa Sekolah Dasar

Asher yang telah sukses dalam pengembangan metode ini pada pembelajaran bahasa asing pada anak-anak. Ia berpendapat bahwa pengucapan langsung pada anak atau siswa mengandung suatu perintah, dan selanjutnya anak atau siswa akan merespon kepada fisiknya sebelum mereka memulai untuk menghasilkan respon verbal atau ucapan. ${ }^{73}$

Metode TPR (Total Physical Response) atau Respon Fisik Total adalah suatu metode pengajaran bahasa yang dibangun berdasarkan kordinasi ujaran dan tindakan, metode ini berupaya mengajarkan bahasa melalui kegiatan fisik atau aktivitas motorik (gerakan). Bahasa diajarkan dengan cara mengaktifkan seluruh gerakan tubuh. Metode ini ditopang pula oleh disiplin ilmu lain, misalnya psikologi perkembangan, teori pembelajaran, pedagogik humanistik, dan juga prosedur-prosedur pengajaran bahasa yang dikemukakan oleh Horld and Dorothy Palmer (1925). ${ }^{74}$ Berdasarkan penjelasan diatas dapat disimpulkan bahwa metode TPR merupakan suatu metode pembelajaran bahasa yang dalam pelaksanaannya menggunakan kegiatan fisik atau gerakan.

\section{Desain Metode Total Physical Response}

Tahap pertama pembelajaran adalah penyajian model. Guru memberikan perintah kepada beberapa orang siswa, lalu

73 Tim Dosen, Ragam Model Pembelajaran Di Sekolah Dasar, (Sumedang: UPI Sumedang Press, 2015), hlm. 168-169.

${ }^{74}$ Kamil Ramma dan Ahmad Hifni, Pengantar Metodologi Pembelajaran Bahasa Arab, (Yogyakarta: IAIN Antasari Press, 2015), hlm. 106. 
Ary Kurniawati, Nurhapsari Pradnya Paramita, Dailatus Syamsiyah : Pengaruh Metode Total Physical Response Terhadap Penguasaan Mufrodat

melaksanakan tindakan-tindakan bersama mereka. Pada tahap kedua, beberapa siswa tersebut menunjukan bahwa mereka dapat memahami perintah-perintah tersebut dengan melaksanakan langsung sendirian. Para siswa yang semula hanya mengamati juga mempunyai peluang untuk memperhatikan pemahaman mereka.

Dalam metode ini guru memainkan peran sebagai pengarah yang aktif. Gurulah yang memutuskan apa yang harus diajarkan. Gurulah yang menjadi model dan menyajikan materi baru, dan yang memilih materi pendukung untuk digunakan dalam kelas. Meskipun demikian guru tetap harus lebih banyak memberikan peluang kepada siswanya. Dalam metode respon fisik total para siswa mempunyai peran utama sebagai pendengar dan pelaksana gerakan. Mereka mendengarkan dengan penuh perhatian dan menanggapi secara fisik terhadap perintah-perintah yang diberikan guru. Siswa juga diharapkan untuk mengenali dan bereaksi terhadap kombinasi-kombinasi baru dari materi yang telah diajarkan sebelumnya. Mereka didorong untuk berbicara ketika mereka merasa siap untuk berbicara.

Metode ini secara umum tidak ada teks pokok pelajaran, karenanya berbagai benda dan realita memainkan peran penting. Untuk siswa yang benar-benar pemula, pengajaran bisa jadi tidak memerlukan pemakaian materi pengajaran, karena suara guru tindakan-tindakan, dan isyaratnya sudah menjadi dasar yang cukup untuk aktivitas kelas. Guru bisa menggunakan benda-benda yang biasa ada didalam kelas. Ketika sudah berkembang, guru 
Ary Kurniawati, Nurhapsari Pradnya Paramita, Dailatus Syamsiyah : Pengaruh Metode Total Physical Response Terhadap Penguasaan Mufrodat

Siswa Sekolah Dasar

perlu membuat atau mengumpulkan bahan-bahan untuk mendukung pengajaran, seeprti gambar, realita, slide, dan daftar kata.75 Dalam pembelajaran menggunakan TPR Guru sebagai pengarah, dan siswa mempunyai peran utama sebagai pendengar dan pelaksana gerakan.

Dua teknik yang dapat digunakan dalam metode ini, yaitu teknik memperkenalkan dan teknik bekerja. Teknik memperkenalkan maksudnya cara-cara yang digunakan untuk memperkenalkan perintah atau kosakata baru kepada siswa untuk pertama kalinya. Sedangkan teknik bekerja mengacu pada caracara yang digunakan untuk menjelaskan atau mengkombinasikan perintah-perintah serta kosakata pendukung yang telah dperkenalkan kepada siswa untuk peningkatan dalam bahasa sasaran.

Dalam proses belajar mengajar dengan menggunakan metode TPR ini banyak aktivitas yang dapat dilakukan oleh guru dan siswa antara lain:

1. Latihan dengan menggunakan perintah merupakan ativitas utama yang dilakukan guru didalam kelas dari metode TPR, latihan berguna untuk memperoleh gerakan fisik dan aktivitas siswa.

2. Dialog atau percakapan

75 Ibid, hlm. 108-109 
Ary Kurniawati, Nurhapsari Pradnya Paramita, Dailatus Syamsiyah : Pengaruh Metode Total Physical Response Terhadap Penguasaan Mufrodat

3. Bermain peran (Role Play), dapat dipusatkan pada aktivitas sehari-hari seperti di sekolah, restoran, pasar, dll.

4. Presentasi dengan OHP atau LCD.

5. Aktivitas membaca dan menulis untuk menambah perbendaharaan kata dan juga melatih pada susunan kalimat berdasarkan tenses dan sebagainya.

6. Latihan menyimak

7. Guru memperkenalkan kosakata dengan memperagakan perintah dan kaset. $^{76}$

\section{TPR Untuk Penguasaan Mufrodat}

Mufrodat merupakan salah satu unsur bahasa yang harus dimiliki oleh pembelajar bahasa Arab. Perbendaharaan kosakata bahasa Arab yang memadai dapat menunjang seseorang dalam berkomunikasi dan menulis dengan bahasa tersebut. Dengan demikian, dapat dikatakan bahwa berbicara dan menulis yang merupakan kemahiran berbahasa tidak dapat tidak, harus didukung oleh pengetahuan dan penguasaan kosakata yang kaya, produktif dan aktual.

Kosakata (al-Mufradât) adalah himpunan kata atau khazanah kata yang diketahui oleh seseorang atau entitas lain, atau merupakan bagian dari suatu bahasa tertentu. Menurut Horn, kosakata adalah sekumpulan kata yang membentuk sebuah bahasa.

${ }^{76} \mathrm{Ibid}$, hlm. 112. 
Ary Kurniawati, Nurhapsari Pradnya Paramita, Dailatus Syamsiyah : Pengaruh Metode Total Physical Response Terhadap Penguasaan Mufrodat

Siswa Sekolah Dasar

Peran kosakata dalam menguasai empat kemahiran berbahasa sangat diperlukan sebagaimana yang dinyatakan Vallet adalah bahwa kemampuan untuk memahami empat kemahiran berbahasa tersebut sangat bergantung pada penguasaan kosakata seseorang. ${ }^{77}$ Dari uraian diatas dapat disimpulkan bahwa kosakata atau (alMufrodat) merupakan kumpulan kata-kata yang membentuk bahasa sehingga dapat dipahami oleh seseorang dan dapat digunakan sebagai alat komunikasi.

Untuk menguasai kosa kata diperlukan metode pembelajaran yang sesuai bagi peserta didik. Menurut penelitian Febri \& Umi (2020) terdapat beberapa metode pembelajaran kosa kata yang sesuai dengan tingkatan peserta didik diantaranya adalah metode Mim-Mem (meniru dan menghafal), metode bernyanyi dan metode Total Physical Response (TPR) yang cocok digunakan pada tingkatan awal/dasar (mubtadi'). ${ }^{78}$

Menurut Ahmad Djanan Asifuddin, pembelajaran kosakata (almufradât) yaitu proses penyampaian bahan pembelajaran yang berupa kata atau perbendaharaan kata sebagai unsur dalam pembelajaran bahasa Arab. ${ }^{79}$ Berikut tahapan dan teknik teknik pembelajaran kosakata (al-Mufrodat) atau pengalaman siswa dalam mengenal dan memperoleh makna kata, sebagai berikut :

77 Ibid, hlm 21-24

78 Febry Ramadani S and R Umi Baroroh, "Strategi Dan Metode Pembelajaran Kosakata Bahasa Arab", IJAZ ARABI, 3.2 (2020), 232-53 <https://doi.org/10.18860/ijazarabi.v3i2.10062>.

${ }^{79}$ Hijriyah, hlm. 34. 
Ary Kurniawati, Nurhapsari Pradnya Paramita, Dailatus Syamsiyah : Pengaruh Metode Total Physical Response Terhadap Penguasaan Mufrodat Siswa Sekolah Dasar

1. Mendengarkan kata : Ini merupakan tahapan pertama yaitu dengan memberikan kesempatan kepada siswa untuk mendengarkan kata yang diucapkan guru atau media lain, baik berdiri sendiri maupun di dalam kalimat.

2. Mengucapkan kata : Dalam tahap ini, guru memberi kesempatan kepada siswa untuk mengucapkan kata yang telah didengarnya.

3. Mendapatkan makna kata : Pada tahap ini guru hendaknya menghindari terjemahan dalam memberikan arti kata kepada siswa, karena bila hal itu dilakukan maka tidak akan terjadi komunikasi langsung dalam bahasa yang sedang dipelajari, sementara makna kata pun akan cepat dilupakan oleh siswa.

4. Membaca kata: Setelah melalui tahap mendengar, mengucapkan, dan memahami makna kata-kata (kosakata) baru, guru menulisnya di papan tulis. Kemudian siswa diberikan kesempatan membaca kata tersebut dengan suara keras.

5. Menulis kata : Penguasaan kosakata siswa akan sangat terbantu bilamana ia diminta untuk menulis kata-kata yang baru dipelajarinya (dengar, ucap, paham, baca) mengingat karakteristik kata tersebut masih segar dalam ingatan siswa.

6. Membuat kalimat : Tahap terakhir dari kegiatan pembelajaran kosakata adalah menggunakan kata-kata baru itu dalam sebuah kalimat yang sempurna, baik secara lisan maupun tulisan. ${ }^{80}$

${ }^{80}$ Ahmad Fuad Effendy, Metodologi Pengajaran Bahasa Arab, (Malang: Misykat, 2005), hlm. 40-42. 
Ary Kurniawati, Nurhapsari Pradnya Paramita, Dailatus Syamsiyah : Pengaruh Metode Total Physical Response Terhadap Penguasaan Mufrodat

Siswa Sekolah Dasar

Pengaruh Model TPR Terhadap Penguasaan Mufrodat Di Sekolah Dasar

Proses peneilitian metode total physical response:

1. Peneliti menyusun Rencana Pelaksaan Pembelajaran (RPP), pokok bahasan tentang materi أعضاء الجسم

2. Peneliti menyusun lembar tes lisan yang berupa 15 pertanyaan, dan tes tulis jenis penjodohan 5 pertanyaan.

3. Peneliti menyusun skor soal yang sesuai dengan jumlah aspek yang diamati

4. Peneliti membagi kels menjadi 2, yaitu kelas kontrol dan kelas eksperimen

5. Peneliti melakukan penelitian di kelas eksperimen menggunakan metode TPR, dan kelas kontrol menggunakan metode konvensional/gramatika terjemah

6. Peneliti menguji hipotesis pada kelas eksperimen dan kelas kontrol

\section{Hasil Uji Data Statistik}

Hasil Statistik Deskriptif Data Kelas Kontrol dan Kelas Eksperimen: 
Ary Kurniawati, Nurhapsari Pradnya Paramita, Dailatus Syamsiyah : Pengaruh Metode Total Physical Response Terhadap Penguasaan Mufrodat Siswa Sekolah Dasar

\begin{tabular}{|l|l|l|l|l|l|}
\hline & $\mathrm{N}$ & Minimum & Maximum & Mean & $\begin{array}{c}\text { Std. } \\
\text { Deviation }\end{array}$ \\
\hline $\begin{array}{l}\text { Data Pretest } \\
\text { TPR } \\
\text { Eksperimen }\end{array}$ & 10 & 35.00 & 90.00 & 66.7500 & 17.36256 \\
\hline $\begin{array}{l}\text { Data Postest } \\
\text { TPR } \\
\text { Eksperimen }\end{array}$ & 10 & 75.00 & 100.00 & 90.2500 & 8.61604 \\
\hline $\begin{array}{l}\text { Data Pretest } \\
\text { Kontrol }\end{array}$ & 10 & 35.00 & 77.50 & 60.0000 & 13.94433 \\
\hline $\begin{array}{l}\text { Data Postest } \\
\text { Kontrol }\end{array}$ & 10 & 37.50 & 82.50 & 62.5000 & 14.57738 \\
\hline $\begin{array}{l}\text { Valid N } \\
\text { (listwise) }\end{array}$ & 10 & & & & \\
\hline
\end{tabular}

Keterangan :

$N \quad$ : Jumlah data Minimun : Skor terendah

Maximum :Skor tertinggi Mean : Nilai rata-rata

Std. Deviation : Simpangan baku

Tampilan tabel 5 hasil statistic menunjukan jumlah responden $(\mathrm{N})$ pada kelas eksperimen pretest dan posttest ada 10, dari 10 responden pada hasil pretest nilai siswa terkecil (minimum) adalah 35.00, dan nilai terbesar (maximum) adalah 90.00. Rata-rata nilai (mean) dari 10 responden pada hasil pretest kelas eksperimen sebesar 66.75, dengan standar deviasi sebesar 17.36. Selanjutnya adapun pada hasil posttest kelas eksperimen dari 10 responden nilai siswa terkecil adalah 75.00, dan nilai terbesar adalah 100.00. Rata- 
Ary Kurniawati, Nurhapsari Pradnya Paramita, Dailatus Syamsiyah : Pengaruh Metode Total Physical Response Terhadap Penguasaan Mufrodat

Siswa Sekolah Dasar

rata nilai dari 10 responden hasil posttest sebesar 90.25, dengan standar deviasi sebesar 8.616 .

Hasil kelas kontrol, pretest dan posttest terdapat 10 responden, dari 10 responden pada hasil pretest nilai siswa terkecil adalah 35.00, dan nilai terbesar adalah 77.50. Rata-rata nilai dari 10 siswa sebesar 60.00, dengan standar devasi 13.94. Selanjutnya adapun pada hasil posttest kelas kontrol dari 10 responden nilai siswa terkecil adalah 37.50, dan nilai terbesar adalah 82.50. Ratarata nilai dari 10 responden hasil posttest sebesar 62.50, dengan standar deviasi sebesar 14.57.

\section{Hasil Uji Normalitas Data}

Uji kenormalan dari sampel dapat dilakukan dengan Uji Shapiro-Wilk. ${ }^{81}$ Dasar pengambilan keputusan dalam uji normalitas adalah:

a. Jika sig. (Signifikasi) atau nilai probabilitas $<0.05$, maka data berdistribusi tidak normal

b. Jika sig. (Signifikasi) atau nilai probabilitas $>0.05$, maka data berdistribusi normal

${ }^{81}$ https:// www.konsistensi.com/2013/04/uji-normalitas-data-denganspss.html, akses 6 Oktober 2020 
Ary Kurniawati, Nurhapsari Pradnya Paramita, Dailatus Syamsiyah : Pengaruh Metode Total Physical Response Terhadap Penguasaan Mufrodat Siswa Sekolah Dasar

\section{Tabel 2}

Hasil Uji Normalitas Kelas Eksperimen

\begin{tabular}{|l|r|r|r|r|r|r|}
\hline & \multicolumn{6}{|l|}{ Kolmogorov-Smirnov } \\
\cline { 2 - 8 } & Statistic & \multicolumn{1}{|l|}{ Sf } & \multicolumn{1}{l|}{ Sig. } & Statistic & df & \multicolumn{1}{l|}{ Sig. } \\
\hline $\begin{array}{l}\text { Data Pretest TPR } \\
\text { Eksperimen }\end{array}$ & .183 & 10 & $.200^{*}$ & .959 & 10 & .770 \\
\hline $\begin{array}{l}\text { Data Posttest } \\
\text { TPR Eksperimen }\end{array}$ & .303 & 10 & .010 & .787 & 10 & .010 \\
\hline
\end{tabular}

Pada Tabel 2 diketahui nilai signifikansi Shapiro-Wilk untuk kelas eksperimen Pretest adalah 0,770 lebih besar dari 0,05, sehingga dapat disimpulkan bahwa hasil pretest berdistribusi normal. Sedangkan hasil Posttest kelas eksperimen adalah 0,010 maka lebih kecil dari 0,05, sehingga dapat disimpulkan bahwa hasil posttest kelas eksperimen berdistribusi tidak normal.

Tabel 3

Hasil Uji Normalitas Kelas Kontrol

\begin{tabular}{|c|c|c|c|c|c|c|}
\hline & \multicolumn{3}{|c|}{ Kolmogorov-Smirnova } & \multicolumn{3}{|c|}{ Shapiro-Wilk } \\
\hline & Statistic & $\mathrm{df}$ & Sig. & Statistic & $\mathrm{df}$ & Sig. \\
\hline $\begin{array}{l}\text { Data Pretest TPR } \\
\text { Kontrol }\end{array}$ & .200 & 10 & $.200^{*}$ & .926 & 10 & .412 \\
\hline $\begin{array}{l}\text { Data Postest TPR } \\
\text { Kontrol }\end{array}$ & 168 & 10 & $.200^{*}$ & .950 & 10 & .664 \\
\hline
\end{tabular}

Pada tabel 3 diketahui nilai signifikansi Shapiro-Wilk untuk kelas kontrol Pretest adalah 0,412 lebih besar dari 0,05, sehingga dapat disimpulkan bahwa hasil pretest berdistribusi normal. Sedangkan hasil Posttest kelas kontrol adalah 0,664 maka lebih 
Ary Kurniawati, Nurhapsari Pradnya Paramita, Dailatus Syamsiyah : Pengaruh Metode Total Physical Response Terhadap Penguasaan Mufrodat

Siswa Sekolah Dasar

besar dari 0,05, sehingga dapat disimpulkan bahwa hasil posttest kelas kontrol berdistribusi normal.

\section{Uji Beda Kelas Eksperimen}

Diketahui pada uji normalitas pada tabel 2 bahwa hasil pretest berdisitribusi normal, sedangkan hasil posttest berdistribusi tidak normal, maka uji beda yang peneliti lakukan menggunakan uji Wilcoxon.

Berdasarkan hasil pada tabel 4 diperoleh nilai Asymp.Sig. (2tailed) sebesar 0,005. Karena nilai sig 0,005 < 0,05 dengan demikian dapat disimpulkan bahwa terdapat perbedaan yang signifikan antara sebelum dan sesudah menggunakan metode TPR

\section{Uji Beda Kelas Kontrol}

Diketahui pada hasil uji normalitas kelas kontrol pada tabel 4 bahwa hasil pretest dan postest pada kelompok kontrol berdisitribusi normal, maka uji beda yang digunakan uji Paired Sample T Test.

\section{Tabel 5}

\section{Hasil Uji Beda Kelas Kontrol}

\begin{tabular}{|c|c|c|c|c|c|c|c|c|c|}
\hline & \multicolumn{5}{|c|}{ Paired Differences } & \multirow[t]{3}{*}{$\mathrm{t}$} & \multirow[t]{3}{*}{$\mathrm{df}$} & \multirow{3}{*}{$\begin{array}{l}\text { Sig. (2- } \\
\text { tailed) }\end{array}$} \\
\hline & & \multirow[t]{2}{*}{ Mean } & \multirow[t]{2}{*}{$\begin{array}{l}\text { Std. } \\
\text { Deviation }\end{array}$} & \multirow[t]{2}{*}{$\begin{array}{l}\text { Std. } \\
\text { Error } \\
\text { Mean }\end{array}$} & \multicolumn{2}{|c|}{$\begin{array}{l}\text { 95\% Confidence } \\
\text { Interval of the } \\
\text { Difference }\end{array}$} & & & \\
\hline & & & & & Lower & Upper & & & \\
\hline Pair 1 & $\begin{array}{l}\text { Data Pretest } \\
\text { TPR Kontrol - } \\
\text { Data Posttest } \\
\text { TPR Kontrol }\end{array}$ & -2.50000 & 3.72678 & 1.17851 & -5.16598 & .16598 & -2.121 & 9 & .063 \\
\hline
\end{tabular}


Ary Kurniawati, Nurhapsari Pradnya Paramita, Dailatus Syamsiyah : Pengaruh Metode Total Physical Response Terhadap Penguasaan Mufrodat Siswa Sekolah Dasar

Berdasarkan hasil pada tabel 5 diperoleh bahwa $t$ hitung adalah -2.121 dengan nilai probabilitas 0,063. Oleh karena probabilitas 0,063 > 0,05, maka Ho diterima, yang berarti hasil pretest dan posttest pada pemahaman mufrodat siswa tidak terdapat perbedaan yang signifikan.

\section{Uji Hipotesis Data}

Setelah dilakukan uji normalitas dan uji beda terhadap kelas eksperimen dan kelas kontrol pada hasil pemahaman mufrodat siswa mata pelajaran bahasa arab, selanjutnya akan dilakukan analisa data untuk menguji hipotesis yang telah diajukan. Uji hipotesis ini dilakukan untuk mengetahui adakah pengaruh metode total physical response terhadap pemahaman mufrodat siswa mata pelajaran bahasa arab siswa SD.

Hipotesis statistik dalam penelitian ini adalah :

1. $\mathrm{H}_{\mathrm{o}}$ : Tidak ada pengaruh yang signifikan penerapan metode total physical response terhadap tingkat pemahaman mufrodat siswa pada mata pelajaran bahasa arab kelas V SD Qurrota A'yun Yogyakarta

2. $\mathrm{H}_{\mathrm{a}}$ : Ada pengaruh yang signifikan penerapan metode total physical response terhadap tingkat pemahaman mufrodat siswa pada mata pelajaran bahasa arab kelas V SD Qurrota A'yun Yogyakarta

Setelah di uji normalitas data penelitian merupakan data yang tidak berdistribusi normal dan jumlah sampel kurang dari 30, 
Ary Kurniawati, Nurhapsari Pradnya Paramita, Dailatus Syamsiyah : Pengaruh Metode Total Physical Response Terhadap Penguasaan Mufrodat

Siswa Sekolah Dasar

maka uji hipotesis yang dilakukan oleh peneliti menggunakan uji Mann Whitney. Adapun dasar pengambilan keputusan yang dijadikan acuan dalam uji mann-whitney:

1. Jika nilai signifikansi atau Asymp.Sig. (2-tailed) lebih kecil dari probabilitas 0,05 maka hipotesis "Ha diterima"

2. Namun jika nilai signifikansi atau Asymp. Sig> (2-tailed) lebih besar dari probabilitas 0,05 maka hipotesis "Ha ditolak"

\section{Tabel 6}

\section{Hasil Uji Hipotesis Kelas Eksperimen dan Kelas Kontrol}

\begin{tabular}{|l|r|}
\hline & \multicolumn{2}{|c|}{ Data } \\
\hline Mann-Whitney U & 5.000 \\
Wilcoxon W & 60.000 \\
Z & -3.424 \\
Asymp. Sig. (2-tailed) & .001 \\
Exact Sig. [2*(1-tailed Sig.)] & $.000^{\mathrm{b}}$ \\
\hline
\end{tabular}

b. Not corrected for ties

Berdasarkan hasil test statistics dalam uji mann-whitney pada tabel 6 diketahui bahwa nilai Asymp.Sig. (2-tailed) sebesar 0,000 lebih kecil dari nilai probabilitas 0,05. Oleh karena itu, sebagaimana dasar pengambilan keputusan uji mann whitney di atas maka dapat disimpulkan bahwa "Ha diterima". Dengan demikian dapat dikatakan bahwa ada perbedaan pemahaman mufrodat antara kelas yang menggunakan metode total physical response dengan kelas yang menggunakan metode konvensional. Karena terdapat perbedaan yang signifikan maka hipotesis penelitian, dpat 
Ary Kurniawati, Nurhapsari Pradnya Paramita, Dailatus Syamsiyah : Pengaruh Metode Total Physical Response Terhadap Penguasaan Mufrodat Siswa Sekolah Dasar

dikatakan bahwa ada pengaruh penggunaan metode total physical response terhadap pemahaman mufrodat pada pelajaran bahasa arab kelas V SD Qurrota A'yun Yogyakarta tahun ajaran 2020-2021.

\section{Kesimpulan}

Berdasarkan hasil perhitungan uji beda pada kelas eksperimen yang menggunakan uji Wilcoxon pada tabel diperoleh nilai Asymp.Sig. (2-tailed) sebesar 0,005. Karena nilai sig 0,005 < 0,05 dengan demikian dapat disimpulkan bahwa terdapat perbedaan yang signifikan antara sebelum dan sesudah menggunakan metode TPR. Selanjutnya berdasarkan hipotesis yang dilakukan melalui uji mann-whitney diketahui bahwa nilai Asymp.Sig. (2-tailed) sebesar 0,000 lebih kecil dari nilai probabilitas 0,05. Dengan demikian dapat dikatakan bahwa ada perbedaan penguasaan mufrodat antara kelas yang menggunakan metode total physical response dengan kelas yang menggunakan metode konvensional. Hasil penelitian ini menunjukkan bahwa penggunaan metode total physical response memberikan pengaruh terhadap penguasaan mufrodat pada pelajaran bahasa arab kelas $\mathrm{V}$ SD Qurrota A'yun Yogyakarta.

Berdasarkan hasil penelitian ini, dapat dibuktikan bahwa adanya inovasi metode dalam pembelajaran sangat diperlukan. Penggunaan metode konvesional (Gramatika terjemah) dalam penelitian ini cenderung kurang dapat meng-upgrade kemampuan siswa. Inovasi metode pembelajaran ini bertujuan untuk 
Ary Kurniawati, Nurhapsari Pradnya Paramita, Dailatus Syamsiyah : Pengaruh Metode Total Physical Response Terhadap Penguasaan Mufrodat

Siswa Sekolah Dasar

mengoptimalkan masing-masing kecerdasan yang dimiliki siswa, sehingga hasil pembelajaran lebih optimal.

\section{IHTIMAM}


Ary Kurniawati, Nurhapsari Pradnya Paramita, Dailatus Syamsiyah : Pengaruh Metode Total Physical Response Terhadap Penguasaan Mufrodat Siswa Sekolah Dasar

\section{Daftar Pustaka}

Abdul Chaer, Psikolinguistik Kajian Teoritik (Jakarta: Rineka Cipta, 2003)

Abdul Munip, dkk, 'Pedoman Penulisan Skripsi Jurusan Pendidikan Bahasa Arab Fakultas Ilmu Tarbiyah Dan Keguruan UIN Sunan Kalijaga Yogyakarta', 2015

Ahmad Fuad Effendy, Metodologi Pengajaran Bahasa Arab (Malang: Misykat, 2005)

Ahmad Hifni dan Kamil Ramma, Pengantar Metodologi Pembelajaran Bahasa Arab (Kalimantan: IAIN Antasari Press, 2015)

Ahmad Izzan Metodologi Pembelajaran Bahasa Arab, ( Bandung: Penerbit HUMANIORA, 2015)

Ahmad Muradi Pembelajaran Menulis Bahasa Arab: Dalam Perspektif Komunikatif (Jakarta: KENCANA, 2015)

Ahmad Susanto, Teori Belajar Dan Pembelajaran Di Sekolah Dasar (KENCANA, 2016)

Ahmad Syagif, and Anwar Sadat, 'Penerapan Metode Total Physical Response (TPR) Dalam Pembelajaran Maharah Kitabah', Al-Af'idah, 2.2 (2018)Albert Efendi Pohan, Konsep Pembelajaran Daring Berbasis Pendekatan Ilmiah, (Purwodadi : CV Sarnu Untung, 2020)

Andi Prastowo, Menyusun Rencana Pelaksanaan Pembelajaran (RPP) Tematik Terpadu Implementasi Kurikulum 2013 Untuk SD/MI, II (Jakarta: KENCANA, 2017)

Andri Wicaksono, Ahmad Subhan, Teori Pembelajaran Bahasa, (Yogyakarta: Penerbit Garudhawaca, 2016) 
Ary Kurniawati, Nurhapsari Pradnya Paramita, Dailatus Syamsiyah : Pengaruh Metode Total Physical Response Terhadap Penguasaan Mufrodat

Siswa Sekolah Dasar

Enang Sudrajat, Syatibi, and Abdul Aziz Sidqi, Cordova Al-Quran E Terjemah (Jakarta: Syaamil Quran, 2009)

Febry Ramadani, and R Umi Baroroh, 'Strategies And Methods Of Learning Arabic Vocabulary Strategi Dan Metode Pembelajaran Kosakata Bahasa Arab', IJAZ ARABI, 3.2 (2020)

Fitria Febriantic Putri, Keefektifan Penggunaan Metode TPR (Total Physical Response) Dalam Pembelajaran Keterampilan Berbicara Dan Keterampilan Menulis Bahasa Arab Siswa Kelas VII MTS Al Anwar Sarang Rembang'

Kamil Ramma Oensyar, Ahmad Hifni, Pengantar Metodologi Pembelajaran Bahasa Arab, I (Yogyakarta: IAIN Antasari Press, 2015)

Kusnadi, Metode Pembelajaran Kolaboratif Penggunaan Tools SPSS Dan Video Scribe, ed. by Taofik Muhammad, I (Tasikmalaya: Edu Publisher, 2018)

Konsultan Statistik, https://www.konsultanstatistik.com/2009/03 Luji-beda.html, akses 6 Oktober 2020

Lutfi Abdul Basit, Eksperimentasi Metode Total Physical Response (TPR) Dalam Pembelajaran Maharah Al-Kalam Kelas X SMK Smart Al Muhsin Krapyak Wetan Yogyakarta, 2019

Muhammad Ahsan, dkk, Penerapan Media Pembelajaran Dalam Memperkenalkan Kosa Kata Bahasa Arab (IAIN Parepare Nusantara Press, 2019)

Muhammad Jafar Shodiq, 'Upaya Meningkatkan Kemahiran Berbicara Melalui Metode TPR (Total Physical Response ) Dalam Mata Pelajaran Bahasa Arab Di Kelas Iv A MI', 4 (2012), 21-36

Nabila Nurbiati Zulaini, Nuril MUfidah, Nur Kholis, and Muhammad Afif Amrullah, ‘Pembelajaran Bahasa Arab 
Ary Kurniawati, Nurhapsari Pradnya Paramita, Dailatus Syamsiyah : Pengaruh Metode Total Physical Response Terhadap Penguasaan Mufrodat Siswa Sekolah Dasar

Untuk Madrasah Ibtidaiyah Pada Masa Wabah Covid-19', Al-Mudarris: Journal of Education, 3.1 (2020)

Rizki, Oktaviani,'Penerapan Metode Belajar TPR (Total Physical Response) Dalam Pengenalan Kosa Kata Bahasa Inggris Anak Usia 5-6 Tahun', 2019

Saifudin Hakim, "Pentingnya Mempelajari Bahasa Arab" https:/ / muslim.or.id/31097-pentingnya-mempelajaribahasa-arab.html. akses tanggal 10 Agustus 2020.

Sholihin, Bahasa Arab Buku Pelajaran Bahasa Arab untuk Kelas I Madrasah Ibtidaiyah, ( Bandung: Penerbit Grafindo Media Permata, 2008)

Sugiyono, Metode Penelitian Pendidikan (Kuantitatif, Kualitatif, Kombinasi, RED Dan Penelitian Pendidikan), I (Bandung: ALFABETA, cv, 2019)

Tim Dosen, Ragam Model Pembelajaran Di Sekolah Dasar, ed. by Dadan Djuanda and Maulana, II (Sumedang: UPI Sumedang Press, 2015)

Umi Hijriyah, Analisis Pembelajaran Mufrodat Dan Struktur Bahasa Arab Di Madrasah Ibtidaiyah, ( Surabaya: Penerbit CV Gemilang, 2018)

Wakhidati Nurrohmah putri, 'Pengaruh Media Pembelajaran Terhadap Motivasi Belajar Bahasa Arab Siswa Madrasah Tsanawiyah', LISANIA: Journal of Arabic Education and Literature, 1.1 (2017),

Widi Astuti, 'Berbagai Strategi Pembelajaran Kosa Kata Bahasa Arab', Jurnal Komunikasi Dan Pendidikan Islam, 5.2 (2016)

Wowo Sunaryo Kuswana,Taksonomi Kognitif Perkembangan Ragam Berpikir (Bandung: Rosdakarya, 2012) 